\title{
Goin' Back ta Da Islan': Migration, Memory and the Marketplace in Bahamian Art
}

\section{lan Gregory Strachan The College of The Bahamas ${ }^{1}$}

\author{
ABSTRACT \\ Wake up early one mornin' \\ Kiss my Mamma goodbye \\ Goin' back ta di Islan' \\ I say, don' worry Mamma, don' cry \\ Ronnie and the Ramblers, "Crown calypso" (1969, track 8) \\ We are who we are \\ Children of the hot lands \\ We build fires every Christmas \\ And pray in earnest for cold weather \\ Jerome Cartwright, "Cold snap" (1993) \\ I told of never coming Winter; \\ The boats dancing gaily in a blue bay; \\ Then I sang of flowers blooming, the wild ocean booming, \\ Thunder walking the streets of the islands in May \\ Robert Elliot Johnson, "The wanderer” (1972)
}

\section{INTRODUCTION}

These three extracts provide an introduction to our subject: the factors affecting the representation of the Bahamian landscape in art. Together they seem to triangulate the subject. The lyrics from a song performed by one of our most celebrated calypsonians, Ronnie Butler, explore the irrepressible nostalgia for a simpler rural past that permeates much of Bahamian secular music produced after Independence in 1973. The second, a poem by Jerome Cartwright, addresses our sense of alienation from our island landscape as a result of the North Atlantic's cultural colonialism. And the last poem, by Robert Elliot Johnson, demonstrates the extent to which Bahamians speak in the language of the tourist brochure when describing their country to outsiders. Migration, memory and the marketplace do not exhaust the list of factors shaping our art, but they are principal players in its production.

We shall see that there are important

\footnotetext{
1 lan Gregory Strachan, Vice President, Office of Communications, The College of The Bahamas, P.O. Box N-4912, Nassau, Bahamas

e-mail: ian.strachan@cob.edu.bs

Acknowledgements: A version of this paper was published in Yinna, vol. 2 (2007), pp. 29-46.

APA reference: Strachan, I. G. (2014). Goin' back ta da islan': Migration, memory and the marketplace in Bahamian art. International Journal of Bahamian Studies, 20(1), 52-62. https://doi.org/10.15362/ijbs.v20i1.213
}

(C) I.G. Strachan, 2014. Journal compilation (CThe International Journal of Bahamian Studies, 2014 
connections between the Bahamian nostalgia for the rural Family Island past and touristic idealizations of Caribbean island life. Whereas Africa often becomes the subject of longing and idealization in Jamaican reggae music, in Bahamian music Da Islan' is a more compelling object of idealization, nostalgia, romanticism and yearning. The three forms of artistic expression we will examine are poetry, music and painting.

The romanticization of the pastoral place is not new in human history. It goes hand in hand with the nostalgia for childhood, for a time of greater innocence. Since the literature of antiquity, City people have pined for the Country, where it was believed people knew each other and knew how to get along, where one was safer, where it has always been imagined that life was easier, there was less suffering, less violence, less greed and evil (Williams, 1973, p. 17). We must remember that many people often think that the present day is worse than the Good Ole Days and that things will get worse before they get better.

So what are the factors affecting notions of home and homeland in The Bahamas? First, we acknowledge that those two terms do not necessarily mean the same thing, particularly in an archipelago where all of the citizens of the country do not live on the same land mass (Bethel, 2000). We must remember that, like many Caribbean nations in which internal migration moves from the rural to the urban locales, The Bahamas has undergone a dramatic population shift which has left the Family Islands under-populated since the 1960s and 1970s, motivated by the search for educational and employment opportunities in the capital. But notions of home are complicated by other factors. In the era of colonialism under Britain, it was the Mother Country and its landscape (like its history, its songs and traditions), which were idealized, the subject of fantasy, of reverence. In the post-Independence Bahamas, the notion is still alive to many that The Bahamas is less "real" as a nation, when compared to our neighbor, the United States. This inferiority complex is not unique to Bahamians; many English-speaking Caribbean societies suffer from it (Cliff, 1995; Naipaul, 1969b). What happened to Bahamians during British colonial rule was a kind of alienation from the very land on which they lived. Bahamians dreamed of one world and lived in another, meaner, cruder one. The same can be said of many of today's American cable, satellite, Netflix and DirectTV watchers. Since Independence, Bahamians have come more and more under the influence of the United States, as had the entire world since the end of World War II. For instance, the majority of tourists who come to The Bahamas are of United States provenance.

The Bahamian problem of place is further complicated by the fact that Afro-Bahamians descend from slaves who never wished to come to this country, who had a home that was elsewhere, in Africa. The loss of Africa, some have argued, has contributed to a sense of restlessness and a lack of connection with the land among Caribbean people. We are a people, in other words, who mourn the loss of that which we never knew; in this century we perhaps have no archaeological link to the land. There are no ruins to look upon. We cannot trace our ancestry in these islands back into the mists of antiquity. Our African past, even our past in these islands rests on what, in the American context, Michael Dyson refers to as the "ash heap of dismemory" (1993, p. 32).

We must also bear in mind that despite universal suffrage and independence, the formerly enslaved and colonized people still do not feel that they are in full possession and control of the institutions that employ them, or of the economy that feeds them. The State is not the same as the Community in the eyes of the people. Rather, it is often viewed as an 
adversary-something to use whenever possible, but more importantly, something around which to maneuver for one's individual best interest. There is little thought of hurting the nation with one's illegalities, one's mediocrity, indiscipline or low productivity, only of helping oneself and one's family, and avoiding the law. ${ }^{2}$

These circumstances contribute to a disregard for the landscape among many, a lack of reverence for the place on which they walk. This is characteristic of a people who still feel no stake in the place in which they find themselves, no need to ensure its preservation for future generations. The rampant pollution and widespread disregard for historic buildings and land formations attest to this. (I say this being fully aware of the phenomenon of Family Island generation land, which ensures that all black Bahamians can comfort themselves with the thought of imaginary wealth and acreage beyond the limits of desire, but which actually remains a key to the disinheritance of the masses, as the heirs to these hundreds of acres remain in debt and crammed into Nassau duplexes and Government low-cost subdivisions.)

It is against the backdrop of this tradition of colonial and neocolonial negation of their own landscape's right to exist as a real place, against this tradition of disinheritance, and this sense of exile while at home, that Bahamian artists engage in the necessarily political act of representing and celebrating Home and Homeland as they wish to define them, rather than remaining the coerced witnesses of someone else's celebrations of place, of culture, the involuntary witnesses of the developed world's preoccupation with its own triumphant march toward the Western horizon. This is why Nobel Laureate Derek

2 Chinua Achebe makes similar observations in The Trouble with Nigeria. One might also note Naipaul's description of Trinidad as a "picaroon society" in The Middle Passage (London: Penguin, 1969), pp. 78-79.
Walcott could recollect in a recent essay that there was something terrifying and exciting about writing the word "breadfruit" on a piece of paper in 1945 (1996, p. 26). One was elevating in art that which was too mean, too mundane, too native to be celebrated in verse. Of course, the Bahamian artist's representations of home are informed by yet another colonizing force, that of tourism and its highly marketable conception of the Bahama Islands as places not only of natural beauty but also of bliss, innocence, forgetfulness, and tranquility.

There are a number of ways in which the fact of migration becomes manifest in Bahamian art. The forced migration of blacks from Africa becomes the subject of consideration for a number of Bahamian artists, particularly poets and musicians, but some visual artists as well. Second, migration becomes a subject of Bahamian art through calls for tourists to come and taste the sweet island life. This is most overt in our music. And third, the disenchantment with the urban experience of New Providence and the nostalgia for what is perceived as the more peaceful and community-oriented experience of the Family Islands become another subject of the art, particularly popular songs.

It should be noted that Africa has not been ignored in post-Independence Bahamian art. A number of artists have drawn attention to our history of forced migration through slavery. Poems such as Robert Elliott Johnson's "East Street," and "Sailing West" (1972), Livingston Malcolm's "In the Distance of My Mind" (1979) and Christian Campbell's ironically titled poem "Paradise" (1999), display a consciousness of the loss of Africa and the legacy of slavery. These writers view Africa as the unacknowledged yet fundamental force of Bahamian culture. They seek to raise the consciousness of their readers to the fact that even as they are Bahamians they are Africans. 
Patrick Rahming's poem "Slave Name" (1993) describes the process under which colonial education deepened the severance from Africa that bondage and transplantation had inflicted upon Bahamians. The persona of this poem was taught that English history was the only real history. He was denied knowledge of his ancestors in The Bahamas who were slaves, and he was denied knowledge of African ways of life that predated colonialism. Rahming was also responsible for recording the song, "Mwale" (1996, track 9), a ballad that charts the capture of an African, his experience of the Middle Passage, his subjugation in The Bahamas and the achievement of a new personhood by his ancestors. Exuma the Obeah Man (Tony McKay) not only called for justice and compensation for years of black servitude in his song "Pay Me What You Owe Me" (1972, track 6) but he also makes very explicit reference in his song, "Walking Home" (1972, track 8) to the folk belief that blacks could fly back to Africa. All these artists are a part of an intellectual community in The Bahamas that is not so much calling for repatriation to Africa as for a more acute historical consciousness among Bahamians. The focus on Africa in the poetry and music has its corollary in the artwork of visual artists such as Stan Burnside and John Beadle, where African mask motifs meet Junkanoo colour to form a compelling black Bahamian spiritual and cultural response to colonialism, past and present. The moving renditions of black Bahamians Max Taylor, Erica James and Lillian Blades are also useful examples.

We should note, though, that the modern works of Rahming or Exuma are probably not the first time Africa has been the subject of song in The Bahamas. The anthems and spirituals sung by Bahamian slaves and still sung by their descendants to this very day, many of which can be traced to the plantations of Georgia and the Carolinas, are songs of longing for Home. In 1783, after the American War of Independence, Loyalists came to The Bahamas with their slaves (Albury, 1988, p. 108). One can reasonably imagine that for the Bahamian slave transplanted from Georgia who sang of crossing Jordan and seeing that beautiful shore, this imagined destination could have been any of three places. Obviously, it would mean heaven and the hereafter. Second, it could be the longed-for Georgia and Carolina coasts. But also the longing to see the shore on the other side could very well be the manifestation of the belief that in death the souls of slaves returned to Africa. So today, when our elders sing that they are "going home on the morning train," we must truly wonder which home was originally intended. The lyrics below were recorded by Peter Siegel and Jody Stecher and first released in 1978. Sung by the Pinder family, these lyrics typify the potential multivalence of Bahamian spirituals.

Oh Lord, I want you take me over the tide

I cry to the Lord, Jesus,

Take me over the tide

When my work on earth is ended

And I cannot work no longer

O Lord, Jesus, take me over the tide.

(Siegel \& Stecher, 1988)

The migration of tourists has been a subject of Bahamian musical expression since the 1940s, probably earlier. George Symonette's song "Little Nassau" (1955, track 1) celebrated the tourist experience and invited the white foreigner to come to the Bahamas and live the life of a big shot while on vacation. In the post-Independence period, songs have offered the natural beauty of the nation, the food, the culture and the friendliness of the people to the dollar-spending outsider for his/her enjoyment and consumption. Marvin Henfield's "Come Down, It's Better in the Bahamas", Frank Penn and The Esquires' "Bahamas" (1973, track B2), Raphael 
Munnings' "Bahamas Experience" (1986, side A), Nita's "Good Lord" (1998, track 8, written by Norris Carroll), and King Eric and His Knights' “Once is Not Enuff” (1970s, track 1, written by Eric Minns) are all fine examples of this trend:

Once is not enough

Even twice, you don't see all a we stuff

Come back for some conch

Peas and rice and guava duff

Cause when you visit the Bahamas

Once is not enough.

Considering that most Bahamian musicians have only been able to earn a living by performing for tourists over the past 30 years, and that tourism is not only our principal employer but is also heavily promoted by what Althusser (1984) calls "state ideological apparatuses," like the media and the schools, it is no wonder that some songwriters have either taken the initiative or been asked to compose tourist songs. That these songs have had tremendous popularity among Bahamians speaks to the extent to which Bahamians take pride in a tourist vision of The Bahamas as a Paradise. This rhetoric has been met with a degree of approval even if people really know better. Such songs have fed Bahamian national pride and are probably not seen as being any different from other songs expressing pride in the place of our birth, like Smokey 007 and The Surgeons' "Bahamas You Born There" (1980s, track 1A). Few musical artists have taken tourism to task and addressed some of its negative social effects. Pat Rahming's song "Package Deal" (1996, track 1) stands as a significant exception with its critique of male prostitution in the tourist arena.

As far as critiquing tourism is concerned, Bahamian writers have taken the lead. Marion Bethel's "On a Coral Cay" (2008), Patricia Glinton-Meicholas' "No Vacancy in Paradise” (2001), Carlson Limerick's
"Cariconch Quincentennial" (1993) and Obediah Michael Smith's "Wax Paper People" (2003) are examples of poems that have delivered powerful critiques of the tourist economy and its effects on Bahamians socially, culturally and morally. As early as 1971, two years before Bahamian independence, Timothy McCartney expressed grave concerns in his work Neuroses in the Sun about the ethos tourism would engender in the Bahamas. Paintings like "Excerpts from the American Dream" by David Smith are among the few to overtly attack the brochuristic representations of the Bahamian landscape by juxtaposing touristic images with less glamorous vignettes of Bahamian life. Limerick, who likens the exploitation of Bahamians to the use and abuse of the now endangered conch, asks:

Still ravaged by the florid foins

of effluent America

will we find jaded dignity

when custom seeks more virgin soil

as pleasure's surfeit pales?

or are we doomed by torture to

a lifetime on our back? (1993, p. 87)

Among the most popular subjects of Bahamian secular recorded music (along with simple, celebratory dance tunes) is the radical transformation of Bahamian ways of life since majority rule and Independence; more specifically, the transformation in the material conditions of black Bahamians and the ways in which our culture has been adapted to suit that transformation. These songs mourn the loss of Island Life, they reminisce about the Good Old Days in The Bahamas, before modernization and urbanization, they offer a kind of cultural nationalism rooted in the rural Bahamian past, rooted in practices, foodways, rituals that preceded the transformation of family structures, the collapse of Family Island settlements, the overpopulation of Nassau, the onslaught of American commercialism. These songs also celebrate 
seasonal returns to the Family Islands for regatta or other trips. The songwriters express pride in the beauty of their respective places of birth, all in contradistinction to Nassau and New Providence. Butler's "Crown Calypso" (1969, track 8), Exuma's "Cat Island Rake and Scrape Band" (1982, track 5), Phil Stubbs' "Beautiful Cat Island" (1995?, track B1), "Down Home" and "Persevere" (1995, tracks 4 and 2), The Magnetics' "Andros Island" (Hit songs from the Bahamas, 1997, track 9) and Geno D's "Inagua" (1996, track 4) are examples.

In these songs, as in the general public discourse about life on Da Islan', certain notions appear consistently. The expression "Da Islan" becomes a metaphor for a particular style of life, one which is to be opposed diametrically to life on New Providence, or in the city of Nassau, as it is broadly conceived. New Providence no longer exists as an island in the popular imagination. It is imagined as having all the amenities and comforts, trappings and problems of the metropolitan city.

$\mathrm{Da}$ Islan' is a place where there is no electricity, or running water, where there is no crime, where everyone knows his neighbor, where anyone can scold your children if they are rude, where children are never impolite, where people work together as a community, where doors are never locked, there is no noise or garbage, where there are no burglar bars, people are Christians, men are faithful to their spouses, etc. Eddie Minnis' song "Nassau People" (1979, track 3) is a comic treatment of this notion. Many Bahamians over the age 40 who talk of the Family Islands will also use the expression "home" to describe the island of their birth and first years, even though they have not lived there for 30 years or more, and seldom, if ever, return.

We should also note that, because of their landscapes, visits to outlying New Providence settlements like Adelaide and Gambier elicit remarks like "It jus' like Da Islan' out there." Clearly then, Da Islan' is a kind of spatial and temporal metaphor: it signifies a particular Bahamian space other than Nassau but one to which Nassauvians can claim familiarity and affinity. It also represents a moment, a time, in two senses: to go to Da Islan' is to go to another time, and talk of Da Islan' is talk of the past of most Bahamians, a past which is lost to them. To talk of the past when there was no crime and men were good, children spoke only when spoken to and learned the Golden Rule, is to inhabit the space of Da Islan'. Intrinsic in the concept of Islan' life, then, is a conservatism masked by nostalgia. Even when Nassauvians say they can remember when in Nassau people had respect for their elders and children were safe walking home from school, they are saying Nassau was like Da Islan' in this way. So a song like Sweet Emily's "Bring Back the Good Ole Days" (1998, track 7) inhabits the same nostalgic space as a song like "Down Home" by Phil Stubbs (1995, track 4).

Winston Saunders' series of plays The Nehemiah Chronicles (1996) also addresses the dramatic transformation in Bahamian lifestyles since majority rule ushered in rapid development. And though these plays do not fail to highlight the inequities that existed in The Bahamas along colour lines, they also fall into nostalgia for a time when, to put it simply, Bahamians were more civil to each other.

A number of books have been published since black majority rule in 1967, documenting Bahamian lifeways prior to the social and economic transformations that modernized the country. The most famous and successful of these is probably Bain Town by Cleveland Eneas (1976). Visual artists have plugged into the romanticisation of life in the Family Islands, and, being cognizant of the appeal of 
the quaint among people of the more developed world who are searching for relics of the pre-industrial world, they have crafted images which simultaneously appeal to the Bahamian longing for a return home and to the tourist wish for an Eden. Their portrayals are of perpetual sunshine, hibiscus and coconut trees, flamingoes and egrets, lovely wooden colonial homes bordered by bougainvillea, Poinciana trees in bloom, quaint little harbours where the water is never rough and the sky never grey, picturesque regatta sloops with poised black male sailors, and noble old folk standing outside their limestone or clapboard houses.

These paintings could easily be mistaken for tourist postcards. And when artists with this tendency depict Nassauvians, they again choose to represent them inhabiting that metaphorical Islan' space. They may portray clapboards and poor children but they are colourful and picturesque; they are one with the palm trees and flowers, a part of the local colour. The black Bahamian fisherman in Nassau Harbour is part of this also; he is a living tourist landmark, a representation of who is as close to nature as people in the islands are. In this way, a number of postIndependence artists are no different in their portrayals of black Bahamians than Winslow Homer more than 100 years ago depicting what he considered to be primitive native black fishermen in pieces like "The Turtle Pond."

Dorman Stubbs, Eddie Minnis and his daughters Nicole and Roshanne, Alton Lowe and Ricardo Knowles typify this style. Theirs is a mode of representation that is often reminiscent of 19th century illustrations that can be found in American and British travel books and magazines. There is a fetishisation of objects that come to symbolize the past, particularly colonial homes or old clapboard houses. This is, of course, a feature of modern tourism the world over-the search for the authentic object of the past. The latest monstrosity built by an Andros drug dealer or his lawyer is never represented in the work of these artists. The Poinciana tree is a favourite subject of Bahamian pastoral art and variations on this theme can be found in banks, hotels, law firms, doctors' offices and restaurants throughout the nation. This indicates the success of this kind of art not only with tourists but also with affluent Bahamians who frequent art shows in the capital.

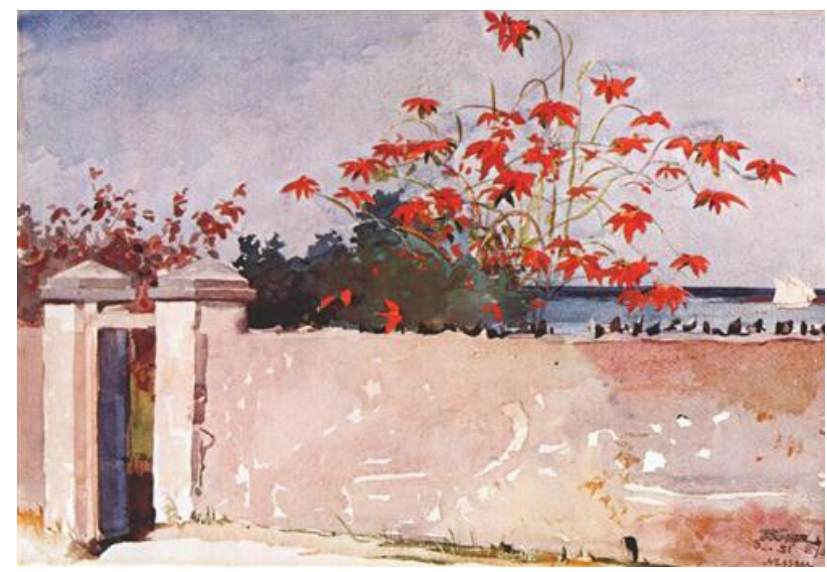

Figure 1: Winslow Homer, A Wall, Nassau. 1898. Retrieved from http://www.wikiart.org/en/winslowhomer/a-wall-nassau

The painting "Regatta Fever" by Dorman Stubbs offers us the typical treatment of regatta that so many photographers and painters have composed in the last thirty years. Drunken men and women in "poom poom" shorts, another, perhaps more profound part of the regatta experience, are never seen. This image is chosen as an emblem of Bahamian-ness, of our past living in the present.

The Family Island then, comes to represent archaism. It must always conform to this sense of being an elsewhere time. Images that suggest modernity in the Family Islands, that suggest that these islands exist in the same world and time as the capital Nassau, with the same resources as Nassau, are usually excluded. These islands are to remain 
repositories of our cultural past in the present; we need them to be so. Interestingly, some recent songs have achieved the twin appeal we have been discussing with respect to paintings. They tap into the modern, urban longing for what is imagined as a less vexing time and they appeal to the romance with The Islands with which the North Atlantic is afflicted. Bahamen's re-make of Ronnie Butler's "Crown Calypso" ("Back to the Island", 1992, track 1) sung in what the performers must have felt assured was the kind of Caribbean accent American listeners would be familiar/comfortable with or expecting, talks of going back to Da Islan's and lists those islands, telling the visitor to go there. Certainly Bahamians don't need to be told which islands they can go to in their own country.

In a different kind of twist, Geno D's "Inagua" (1996, track 4) seems to actually be encouraging Bahamians to become tourists and visit the country's best kept secret. It asks, "Where you gonna go nex' year/What you gonna do?" And instead of saying come to The Bahamas, it says come to Inagua. The song, "Harbour Island" by the Brilanders (Keep the Vide Alive, 2002, track 1), also sounds like an advertisement for local tourism.

What are we to make of this practice of idealizing the Family Islands? As I have stated earlier, the tendency to present the past as a Golden Age is common to many cultures in recorded history. It is a fact that there was less crime in the common sense of it, that communities were more cohesive and that codes of behavior were more strictly enforced. It is also true that there was less divorce, less illegitimate teenage pregnancy and fewer reasons for people to lock their doors. Many Family Island settlements still have a low occurrence of crime. But these phenomena were all products of particular historical, social, demographic and economic circumstances.

For instance, 15 or 16 was not an abnormal age to get married 50 or more years ago. With increased opportunities for women today, opportunities they were denied for far too long, it is now quite rare to see 15-year old Bahamians marry. But teenagers have not ceased sexual activity. I realize that this is not the only explanation for teenage pregnancy, but changes such as these are misinterpreted by the advocates of a return to the "good ole days," as signs that we have suddenly lost our morality.

Similarly, communities relied more on cooperation and the sharing of resources in the Family Islands in order to survive prior to Majority Rule and the great population shift. But with increased economic growth and social change there has been an increase in individualism. People are more and more becoming competitors in the game of acquisition than partners in survival. In New Providence one does not necessarily know one's neighbours and they are less likely one's relatives than in the Family Islands.

Certainly, the central authority and organizing power of the Church seems to have diminished since Independence, despite the proliferation of sacred edifices. But although the Church might enforce a degree of discipline we find comforting considering the social tensions and violence The Bahamas has experienced since the late 1980s, the Church also can oppress. We inhabit a much larger community today than our parents and grandparents did and this means that consensus and consent are harder to obtain and maintain. But is this all bad?

Artistic portrayals of the present-day Family Islands choose to ignore that many of these places are poor and abandoned, that opportunities are very limited and they are, in a sense, the third world of The Bahamas. A great many Nassauvians talk about Da Islan' 
but they could not bear returning to it tomorrow to live. Similarly, there is nostalgia for the positive things about the past of the Family Islands but no one wishes to turn back the clock and return to depending on the mailboat for survival, fighting mosquitoes and abandoning the comforts of modern life.

Certainly Bahamians are not to be criticized too harshly for missing aspects of their recent past. Upon leapfrogging into the modern, urban, capitalist, democratic world, a good deal of trouble has come into Bahamian homes. With increased consumerism, drug trafficking, exposure to the violence and commodity worship of the American media, overpopulation, male dysfunction, the proliferation of violent crime, and the decline in a number of pre-independence customs, Bahamians who can remember when red meat was an event, shoes a privilege and a toilet a luxury, are feeling dizzy.

Naturally then, we seem to wish we could slow it all down. We wonder if we are not throwing the baby out with the bath water. And our art, particularly our songs, express this. Few really wish to return to a time when women could not vote, when black people were politically and economically disenfranchised, when the Family Islands were the margins of a marginal colony. This nostalgia shows a society struggling to gets its bearings, a society that has been reeling due to the pace of its own metamorphoses. It would not wish to jettison the economic and political gains of the last 40 years, but it mourns the cultural and social cost of such gains. We particularly mourn the rise in violence and this makes us look fondly to the past. We should remember, however, that there are various kinds of violence, and holding a people politically, spiritually, economically, culturally and socially hostage from 1838 (the end of slavery) to 1967 (Majority Rule) is not exactly an era when lions and lambs played together in flowering fields.
Of course, not all artists have fallen into mystifying the Family Islands and the past. There is a striking difference between Antonius Roberts' portraits of the elderly (repositories of our past) and the kind of "nativization" we see from Alton Lowe. As mentioned earlier, the work of David Smith is notable because he subverts the touristic image with representations of a Bahamianness that is anything but picturesque.

And to be fair to our songwriters, they have not entirely glossed over the unpleasantness of the past in their lyrics. Ronnie Butler's culturally nationalistic song "Burma Road" (1969, track 1) calls for a return to "the bush" but not without a bittersweet sense of humour, as he reminds his listeners that poor black Bahamians once wore flour sacks for clothing. In Phil Stubbs's "Down Home" (1995, track 4) we find much nostalgia, but among his memories of childhood in Cat Island are cold nights sleeping in crocus (burlap) sack blankets. "We didn't have much/Ah, but we had so much love," he tells us. Geno D's equally nostalgic calypso/rap song, "Ya Remember When" (1996, track 1) is another case in point. Although it asks us if we "Remember the old days/Them good old happy days," it also reminds us that the past was a time of racial discrimination that blacks had to fight to eradicate.

In conclusion, the passage that interests Bahamians most is not the passage that brought about the loss of Africa but the passage that brought us from the Family Islands to Nassau. I say this despite the popularity of Jamaican reggae music, which so often uses Africa as a rallying symbol, and despite the popularity of Rastafarianism among young Bahamian males. (I say this bearing in mind that Africa is remembered every day under the surface of things in so much of what we do).

Perhaps the fact that The Bahamas is an 
archipelago, and coming to New Providence required that our parents and grandparents crossed over water, has given "down home" greater symbolic appeal than Africa. Our artists-particularly our musicians-are raising, in a sense, the fundamental questions facing our nation: What type of a people are we to be; how are we to proceed as a nation; what is community? The backward glance at life on Da Islan' and Over da Hill in the good ole days, is also a form of resistance; resistance to what is perceived as the toorapid Americanization and globalization of our way of life. It is an assertion of our difference in the face of globalization's homogenizing power. It is an assertion of our difference in the face of a brand of American colonialism that makes every street a series of McDonald's restaurants, Texaco gas stations, and Walmarts.

But as we begin to assess the value of what we have gained and to consider whether we can afford to lose what we seem intent on jettisoning, our artists and our scholars must lead the way in a more critical consideration of our past, in looking at the past as honestly and as objectively as possible. A keener historical consciousness is needed, and the kind of social critique that does not rely on the impossible wish to return to the way it wassince it never was what we claim it was-but on honest, hard analysis and a vision of the future. All cultures change, and what gets called national identity is often determined by the agenda of the people with the power to name such things and coordinate consent. I am not arguing that there are not waning aspects of our ways of life worth retaining, but such aspects must be proven viable and relevant to the people if they are to survive; otherwise they will fade away. Otherwise they are just tools for the posturing of poets, preachers and politicians who merely wish to manipulate discontent.

\section{REFERENCES}

Achebe, C. (1984). The trouble with Nigeria. Oxford, England: Heinemann.

Albury, P. (1988). The story of the Bahamas. London, England: Macmillan.

Althusser, L. (1984). Ideology and ideological state apparatuses: Notes towards an investigation. In Essays on ideology (pp. 160). London, England: Verso.

Bahamen. (1992). Junkanoo! [CD]. Nassau, Bahamas: Bigbeat.

Bethel, M. (2008). On a coral cay [poem]. Black Renaissance, 8(2/3), 165.

Bethel, N. (2000). Navigations: National identity and the archipelago. Yinna, 1, 2138.

Campbell, C. (1999). Paradise. [poem] The Caribbean Writer, 13.

Cartwright, J. (1993). Cold snap. In I. S.
Cabrera (ed.), From the shallow seas:

Bahamian creative writing today. Havana, Cuba: Casa de las Americas.

Cliff, M. (1994). If I could write this in fire, I would write this in fire. In A. W. Biddle and G. Bein (Eds.). Global voices (pp. 6879). Englewood Cliffs, NJ: Prentice Hall.

Davis, Eugene. (1996). Geno D unveiled [LP recording]. Nassau, Bahamas: Stars.

Dyson, M. (1993). Reflecting black: AfricanAmerican cultural criticism. Minneapolis: University of Minnesota Press.

Eddie Minnis wit der Ramblers. (1979). Island life [LP recording]. Nassau, Bahamas: Pot Luck.

Eneas, C. (1976). Bain Town. Nassau, Bahamas: Superior.

Exuma. (1972). Reincarnation [CD]. New York, NY: Kama Sutra Records. 
Exuma. (1982). Universal [LP recording]. Nassau, Bahamas: Cat Island Records.

Glinton-Meicholas, P. (2001). No vacancy in paradise: A collection of poems. Nassau, Bahamas: Guanima Press.

Henfield, M. (n.d.). Come down it's better in the Bahamas [LP recording]. Nassau, Bahamas.

Hit songs from the Bahamas [CD]. (1997). Freeport, Bahamas: GBI Recording Studios.

Johnson, R. E. (1972). The road. Nassau, Bahamas: Author.

Keep the vibe alive [CD]. (2002). Nassau, Bahamas: Stars.

King Eric and His Knights. (1970s). When you visit the Bahamas...once is not enuff [LP recording]. Nassau, Bahamas: Elite Records.

Limerick, C. (1993). Cariconch quincentennial. In I. S. Cabrera (ed.), From the shallow seas: Bahamian creative writing today (pp. 86-87). Havana, Cuba: Casa de las Americas.

Malcolm, L. R. (1979) A taste of salt. Kingston, Jamaica: GLO Printers.

McCartney, T. O. (1971). Neuroses in the sun. Nassau, Bahamas: Executive Printers.

Munnings, R. (1986). The Bahamas experience. [45 rpm]. USA: Ultrascope.

Naipaul, V. S. (1969). The middle passage. London, England: Penguin.

Naipaul, V. S. (1969b). The mimic men. London, England: Penguin.

Nita. (1998). Nita [CD]. Nassau, Bahamas; Stars.

Rahming, P. (1993). Slave name. In I. S. Cabrera (ed.), From the shallow seas: Bahamian creative writing today (p. 110). Havana, Cuba: Casa de las Americas.
Rahming, P. (1996). Retrospective [CD]. Nassau, Bahamas: Author.

Ronnie \& the Ramblers. (1969). Burma Road: The original. Nassau, Bahamas: Ronnie Records.

Saunders, W. (1996). The Nehemiah chronicles. Nassau, Bahamas: Rosebud.

Siegel, P., \& Stecher, J. (1988). The real Bahamas, volume 1. New York: Nonesuch.

Smith, O. M. (2003). Poems to sit on to shell peas. Nassau, Bahamas: Verse Place.

Smokey 007, \& The Surgeons. (1980?) Bahamas we born there [45 rpm]. Nassau, Bahamas: Compass Point Studios.

Stubbs, P. (1995). Down home [CD]. Freeport, Grand Bahama: Down Home Productions.

Stubbs, P. (1995?). Back to basics [CD]. Freeport, Grand Bahama: Down Home Productions.

Sweet Emily. (1998). Queen of Junkanoo [CD]. Nassau, Bahamas: Stars.

Symonette, G. (1955). Calypso and Goombay rhythms [LP recording]. Nassau, Bahamas: Bahama Records.

The Esquires Ltd. (1973). Independence [LP recording]. Nassau, Bahamas: F. Penn.

The Magnetics, \& Solomon, W. (1979). Andros island [45 rpm]. Freeport, Bahamas: GBI Record Co.

Walcott, D. (1996). The sea is history. In Frontiers of Caribbean literature in English (pp. 22-27). New York: St Martins.

Williams, R. (1973). The country and the city. London, England: Chatto and Windus. 